\title{
Kredibilitas Komunikator dalam Kasus Satinah dan Kasus Kendeng
}

\author{
Yovanca Natalia Pradipta Puteri ${ }^{1, a)}$ \\ Royke R. Siahainenia ${ }^{2}$ \\ Dewi Kartika Sari ${ }^{3}$ \\ ${ }^{1}$ Program Studi Ilmu Komunikasi, Fakultas Ilmu Sosial dan Ilmu Komunikasi Universitas Kristen Satya \\ Wacana, Salatiga \\ ${ }^{a}$ Korespondensi ;yovanatalia@gmail.com \\ ${ }^{2}$ Program Studi Sosiologi, Fakultas Ilmu Sosial dan Ilmu Komunikasi Universitas Kristen Satya Wacana, \\ Salatiga \\ ${ }^{3}$ Program Studi Ilmu Komunikasi, Fakultas Ilmu Sosial dan Ilmu Komunikasi Universitas Kristen Satya \\ Wacana, Salatiga
}

DOl:https://doi.org/10.18196/jkm.101011

Article Info

Article history:

Received 9 Jul 2018

Revised 19 Okt 2018

Accepted 7 Nov 2018

\begin{abstract}
Melanie Subono's involvement in the Satinah Case and Kendeng Case seized the attention of netizens, namely the Indonesian community. Success in completing a case is determined by the actor in building a communication network so as to achieve a common goal. This study uses several concepts about communication networks and the theory of new social movements. The main theory used is the credibility of the communicator. The purpose of the use of this study was to determine the credibility of the communicator played by Melanie Subono in the Satinah case and the Kendeng case. The research method used is descriptive qualitative. The results of the research obtained were differences in the formation of communication networks and social movements in the Satinah case and the Kendeng case. The Social Movement by Melanie Subono in the Satinah case is a type of Alterative Moment social movement and the type of social movement in the Kendeng case is a type of Reformative moment social movement. The Communication Network in the case of Satinah uses Twitter that is connected to the Ministry of Foreign Affairs, while the communication network in the Kendeng case uses Instagram which is connected to Instagram of the Governor of Central Java. Credibility The communicator in the Satinah case refers to aspects of honesty and objectivity, while the communicator's credibility in the Kendeng case refers to the dynamic aspects of the communicator on social media and refers to aspects of honesty.
\end{abstract}

Keywords: Communication Network, Social Movement, Communicator Credibility, Melanie Subono

\section{ABSTRAK}

Keterlibatan Melanie Subono pada Kasus Satinah dan Kasus Kendeng, memiliki daya tarik yang cukup diikuti oleh sebagian besar netizen yaitu masyarakat Indonesia. Keberhasilan dalam menyelesaikan suatu kasus, ditentukan oleh aktor dalam membangun jaringan komunikasi sehingga mencapai tujuan bersama. Penggunaan teori Jaringan Komunikasi dan teori Gerakan Sosial Baru dalam penelitian ini yaitu untuk mengetahui bagaimana Melanie Subono sebagai aktor membangun jaringan komunikasi melalui sosial media dan membuat gerakan sosial untuk mencapai tujuan yang sama. Terbentuknya Jaringan Komunikasi dan Gerakan Sosial, dalam penelitian ini teori Kredibilitas Komunikator melihat apa saja faktor Kredibilitas Komunikator yang diperankan Melanie Subono dalam kasus Satinah dan kasus Kendeng. Penelitian ini bertujuan untuk mengetahui bagaimana Melanie membangun Jaringan Komunikasi dan Gerakan 
Sosial serta mengetahui Kredibilitas Komunikator Melanie Subono dalam kasus Satinah dan kasus Kendeng. Hasil penelitian yang diperoleh adalah relasi pada kasus Satinah dan kasus Kendeng tentunya berbeda dan menentukan keberhasilan dalam menyelesaikan kasus. Gerakan Sosial yang dilakukan Melanie Subono dalam kasus Satinah merupakan tipe gerakan sosial Alterative Moment dan tipe gerakan sosial pada kasus Kendeng merupakan tipe gerakan sosial Reformative moment. Jaringan Komunikasi yang dibangun dan Gerakan Sosial tersebut menentukan Kredibilitas Melanie Subono menjadi Komunikator.

Kata kunci : Jaringan Komunikasi, Gerakan Sosial, Kredibilitas Komunikator, Melanie Subono

\section{PENDAHULUAN}

Melanie Subono, salah satu aktivis perempuan dan tertarik pada kejadian yang menimpa salah satu Tenaga Kerja Indonesia (TKI) bernama Satinah. Melanie Subono memulai gerakannya melalui Twitter yang bertujuan menggerakkan beberapa masyarakat Indonesia untuk mengadakan suatu gerakan massa untuk Satinah. Terlihat dari akun Twitter Melanie Subono yang mengatakan, “@riosimple @kurawa cuma kali ini karna aku dampingin dari awal, jd aku tau terlalu banyak kebohongan di kasus ini yang tidak terlihat oleh orang lain," yang diunggah pada 26 Mei 2014. Jaringan Internet yang semakin berkembang dengan pesat, menjadi salah satu sarana masyarakat untuk terlibat langsung dalam kejadian Satinah. Salah satunya, Twitter digunakan sebagai media untuk menyalurkan berbagai pendapat dalam kejadian Satinah. Kejadian Satinah membuat masyarakat mulai bergerak dengan media sosial di internet. Berdasarkan data Kementerian Perdagangan, media sosial memiliki unsur mendasar adalah fungsi dan layanan jaringan sosial yang berfungsi untuk memfasilitasi beragam orang yang memiliki ketertarikan, minat, kegiatan, latar belakang, kepentingan, tujuan atau korelasi dunia nyata yang sama (Tim Humas, 2014). Keterlibatan Melanie melalui media sosial menjadi sorotan dari berbagai sudut dan mengairahkan kelompok pendukung Satinah untuk memperjuangkan Satinah lolos dari hukuman pancung di Arab Saudi. Sebagai warga negara Indonesia yang mengadu nasib di luar negara Indonesia, menjadi tanggung jawab negara Indonesia.

Melanie mengakui keterlibatannya tidak hanya terlibat melainkan mendampingi kejadian Satinah dari awal, diutarakannya melalui akun twitter pribadinya. Wujud pendampingan Melanie terhadap kejadian Satinah juga adanya aksi penggalangan dana untuk Satinah. Pada berita Beritagar (beritagar.id.com), Melanie melalui akun Twitter-nya mengajak berbagai kalangan untuk membantu Satinah dengan menyampaikan donasi bagi Satinah yang dikirimkan ke rekening BCA Melanie. Hingga pada akhirnya, Satinah dapat bebas dari hukuman pancung dan kembali ke rumahnya di Ungaran, Indonesia (Harry, 2015).

Menurut detik.com (2014), sejak tahun 2006 Satinah sudah mengadu nasibnya sebagai Tenaga Kerja Wanita (TKW) di Arab Saudi. Satinah ditempatkan di Provinsi Al Qassim dan ia bekerja untuk keluarga dari Nura Al Gharib. Suatu pekerjaan, masing-masing memiliki sebuah resiko tersendiri. Diluar harapan Satinah untuk bekerja dengan nyaman dan mendapatkan majikan yang baik dan layak, berbanding kebalik dengan apa yang di bayangkan Satinah. Perlakuan yang kasar dan tidak dihargai diterima Satinah secara terus-menerus oleh majikannya. Pada tahun 2007, Satinah dibenturkan kepalanya oleh majikan perempuannya bernama Nura Al Gharib di dapur tanpa alasan yang jelas. Merasa sudah tak sanggup lagi menahan kekerasan yang di alaminya, Satinah membalas perlakuan kasar tersebut dengan memukulkan adonan roti ke tengkuk Nura hingga Nura tak sadarkan diri. Perbuatan Satinah sudah menghilangkan nyawa majikannya setelah masa koma yang dialami, Nura Al Gharib. Satinah juga mencuri uang tunai majikannya sebanyak 37.970 riyal yang hampir setara dengan Rp 113.910.000,00. Kesadaran diri Satinah, ia menyerahkan dirinya ke kantor polisi setempat dan mengakui kesalahannya. Kasus Satinah menjadikan Satinah diadili pada tahun 2009-2010, hingga pada akhirnya akan di hukum pancung pada 2011(liputan6.com). 
Vol. 10 No. 2

November 2018

Sosok Melanie Subono tidak hanya terlibat pada kejadian Satinah saja. Melanie Subono juga terlibat pada persoalan Kendeng. Melanie Subono turut serta pada demo yang diadakan di depan kantor Gubernur Jawa Tengah, Semarang (solopos.com). Pada Februari 2017, Ganjar Pranowo selaku Gubernur Jawa Tengah mengeluarkan izin pembangunan baru dengan sedikit perubahan wilayah untuk PT. Semen Indonesia di pegunungan Kendeng, Rembang (bbc.com). Pada Maret 2017, petani Kendeng kembali melakukan protes unjuk rasa di depan Istana Negara, Jakarta dengan menyemen kaki mereka (solopos.com). Hingga pada tanggal 20 Maret 2017, petani Kendeng berduka atas meninggalnya Patmi salah satu petani yang terlibat menyemen kakinya dalam aksi unjuk rasa di Istana Negara, Jakarta (detik.com)

Meninggalnya Patmi menimbulkan keprihatinan dan tekad besar untuk melakukan unjuk rasa pembangunan Semen Indonesia di pegunungan Kendeng, Rembang. Kepedulian Melanie Subono terhadap bu Patmi disampaikan melalui akun pribadinya, "Masih diam pak @ ganjarpranowo Pak @jokowi? Selamat Jalan bu... perjuangan ibu tidak sia-sia" (nusantaranet.com). Keterlibatan Melanie Subono juga terlihat pada kehadirannya pada 40 hari memperingati kepergian Patmi di UIN Sunan Kalijaga (merdeka.com).

Kejadian Kendeng di Rembang, pro kontra terjadi bermula adanya sengketa pembangunan Perusahaan Semen Indonesia di Rembang, Jawa Tengah (detik.com, 2017). Obyek sengketa yang dimaksud ialah izin lingkungan kegiatan penambangan dan pembangunan pabrik semen milik PT. Semen Indonesia di pegunungan Kendeng, Kabupaten Rembang, tertanggal 7 Juni 2012 (Kompas.com, 2017). Gerakan penolakan para petani Kendeng melalui unjuk rasa dengan memukul lesung di depan Istana Negara pada 2016, dengan membuahkan hasil pada Oktober 2016 bahwa Mahkamah Agung mengabulkan permintaan petani Kendeng dengan keputusan mencabut perizinan pembangungan PT Semen Indonesia di Kendeng, Rembang (Kompas.com, 2017). Warga Kendeng tetap melakukan demo unjuk rasa di depan kantor Gubernur Jawa Tengah sebagai bentuk kekecewaan, Ganjar Pranowo telah memberikan surat perizinan pembangunan Semen Indonesia di Kendeng.

Penelitian mengenai Satinah sebelumnya oleh Dewi Kartika Sari dan Royke R, berjudul Gerakan Sosial Baru di Ruang Publik Virtual pada Kasus Satinah yang menekankan pada gerakan sosial pada Kasus Satinah. Penulis pada penelitian ini membahas Kasus Satinah dan Kasus Pembangunan Pabrik Semen di Kendeng yang menekankan pada bagaimana komunikator dapat berhasil membentuk sebuah jaringan komunikasi kepada komunikan. Dalam penelitian ini, melihat kredibilitas Melanie Subono sebagai komunikator dan khalayak/masyarakat yang terlibat dalam kasus Satinah dan kasus Pembangunan Pabrik Semen di Kendeng sebagai komunikan. Berdasarkan uraian latar belakang masalah yang telah dijelaskan diatas, maka rumusan masalah dalam penelitian ini adalah bagaimana Melanie Subono membentuk jaringan komunikasi dan gerakan sosial terhadap kasus Satinah dan kasus Pabrik Semen di Kendeng? Kemudian bagaimana kredibilitas Melanie Subono sebagai komunikator dalam membentuk jaringan komunikasi dan gerakan sosial?

Adapun tujuan dari penelitian ini adalah untuk mendeskripsikan pembentukan jaringan komunikasi dan gerakan sosial oleh Melanie Subono pada kasus Satinah dan kasus Kendeng. Selanjutnya, akan mendeskripsikan juga kredibilitas Melanie Subono sebagai Komunikator dalam membentuk jaringan komunikasi dan gerakan sosial.

\section{Tinjauan Pustaka}

\section{Konsep Komunikasi}

Menurut Wilbur Schramm (dalam Suranto: 2005) yang dikutip oleh Seto Herwandito dalam Jurnal Cakrawala Penelitian Sosial (82-83), komunikasi merupakan suatu tindakan melaksanakan kontak antara pengirim dan penerima, dengan bantuan pesan, pengirim dan penerima memiliki beberapa pengalaman bersama yang memberikan arti pada pesan dan simbol yang dikirim oleh pengirim, dan diterima serta ditafsir oleh penerima. Dari definisi tersebut, dapat mengambil suatu dasar bahwa:

- Komunikasi sebagai suatu proses penyampaian gagasan dari seseorang ke orang lain. Proses penyampaian gagasan akan ditentukan pada komunikator bagaimana seorang komunikator menyampaikan pesannya kepada komunikan. Sehingga, keberhasilan pada proses komunikasi ditentukan dari komunikator. 
- Komunikan sebagai obyek yang pasif.

- Komunikasi dapat menciptakan suatu arti terhadap gagasan atau ide yang di sampaikan. Komunikasi terjadi tidak terlepas dari adanya unsur: pengirim pesan, pesan dan penerima pesan. Dalam dasar ini, ketiga unsur tersebut memiliki nilai yang seimbang dalam proses komunikasi. Dengan adanya encoding dan decoding keberhasilan komunikasi akan terjadi dengan informasi dapat bermakna.

Page | $130 \quad$ Komunikator cenderung memiliki peran besar dalam terjadinya proses komunikasi. Bagaimana cara komunikator menyampaikan sebuah pesan atau informasi yang diberikan, menentukan bagaimana pesan atau informasi dapat mencapai tujuan kepada komunikan dengan mendapatkan pesan atau informasi yang sesuai atau sama. Proses komunikasi akan terbentuk sebuah jaringan yang disebut dengan jaringan komunikasi.

\section{Jaringan Komunikasi}

Jaringan dikemukakan dalam buku Newman (2006) yang dikutip oleh Dwi Retno Hapsari (2016) memiliki pengertian seperangkat item yang disebut dengan vertices yang kadang kala dapat disebut dengan nodes, dan koneksi diantaranya adalah edges.

Ilmu Komunikasi menurut Berger dan Chaffe (Wiryanto, 2004) yaitu mencari untuk memahami produksi, pemrosesan dan efek dari simbol serta sistem signal. Dalam komunikasi, interaksi dapat berlangsung jika ada komunikator, message, dan komunikan. Komunikator berperan sebagai pemberi pesan, sedangkan komunikan berperan sebagai penerima pesan. Message adalah pesan yang disampaikan oleh komunikator kepada komunikan.

Jaringan Komunikasi yang dikemukakan oleh Rogres dan Kincaid (1981) dalam jurnal Komunikasi (Hapsari, 2016) memiliki pemahaman bahwa individu-individu yang terkoneksi antara satu dengan individu lainnya secara arus komunikasi yang terpola. Adanya koneksi yang terhubung antar individu, akan terjadi penukaran informasi atau interaksi sosial dalam suatu sistem. Dari penukaran informasi akan terlihat esensi perilaku individu. Pertukaran informasi yang terjadi dilakukan dalam suatu sistem komunikasi interpersonal yang kemudian menjadi pola (Hapsari, 2016).

\section{Inti dari Jaringan Komunikasi}

Membangun pusat jaringan masyarakat diantara para individu adalah kekuatan jaringan yang merujuk pada aktor dan organisasi yang ada (Hapsari, 2016). Jaringan komunikasi dimiliki oleh semua orang yang memiliki struktur sosial. Jaringan komunikasi memiliki 2 inti dalam interaksi yang berlangsung menjadi sebuah pola, yaitu:

Aktor, yaitu jaringan komunikasi melihat fenomena atau peristiwa dari sisi mikro (aktor) bukan makro. Aktor yang memiliki peran lebih daripada individu lainnya. Sehingga, aktor dapat dikatakan menjadi panutan individu lain atau dalam suatu organisasi.

Relasi yaitu bagaimana aktor-aktor tersebut berinteraksi dengan individu lainnya. Dalam struktur komunikasi, aktor lebih dikenal sebagai komunikator. Dimana komunikator berperan untuk menyampaikan informasi atau pesan kepada komunikan melalui media yang digunakannya.

\section{Pengertian Komunikator}

Proses komunikasi akan terjadi bila ada beberapa unsur komunikator, pesan, media dan komunikan. Proses komunikasi dapat diartikan sebagai "transfer informasi" atau pesan dari komunikator sebagai pengirim pesan dan komunikan sebagai penerima pesan (Suprapto, 2009). Menurut Wilbur Schramm, dalam proses komunikasi unsur yang paling utama adalah komunikator, pesan dan komunikan (Suprapto, 2009). Proses komunikasi yang terdapat 3 unsur tersebut akan terjadi proses komunikasi secara langsung.

Komunikan akan mendengarkan dan percaya pada informasi dari komunikator dengan memiliki kredibilitas tertentu yang dimiliki oleh komunikator. Komunikator merupakan yang memberikan pesan atau bahkan dapat membentuk sebuah opini yang akan disampaikan melalui media kepada komunikan.

\section{Kredibilitas Komunikator}

Kredibilitas memiliki pengertian sebagai seperangkat presepsi dalam mengkomunikasikan sifat-sifat komunikator (Siagian, 2012). Definisi tersebut terbagi menjadi 2 hal yaitu: 1) 
Kredibilitas adalah presepsi komunikate artinya tidak inheren dalam diri komunikator; 2) Kredibilitas berkenaan dengan sifat-sifat yang dimiliki oleh komunikator. Menurut Efendy (2012) keberhasilan komunikasi ditentukan juga oleh orang yang menyampaikan pesan yang disebut komunikator (Siagian, 2012). Hal tersebut ditentukan dari adanya sumber kredibilitas sebagai kredibilitas komunikator.

Kredibilitas komunikasi akan menentukan keberhasilan dari proses penyampaian pesan yang terjadi kepada khalayak/komunikan. Menurut Aristoteles yang dikutip oleh Haidir Fitra Siagian dalam jurnal berjudul Pengaruh Kredibilitas Komunikator Politik Untuk Mendapatkan Dukungan Khalayak Dalam Pemilihan Umum (287) menyatakan kredibilitas komunikator memiliki karakter sifat ethos. Ethos yang memiliki pengertian good will (maksud baik), good sense (pikiran baik), good moral character (karakter yang baik). Ethos menjadi karakter sifat komunikator yang kuat dalam proses komunikasi yang bertujuan untuk mengubah sikap bahkan pola pikir khalayak/komunikan. Dengan sifat ethos, komunikator dapat mencapai tujuannya.

Sumber dari kredibilitas komunikator terdapat beberapa faktor (Siagian, 2012), yaitu:

- Faktor Kejujuran, dapat diukur pada skala benar-salah, percaya-tidak percaya, jujur-tidak jujur, adil-tidak adil.

- Faktor Profesionalisme, dapat diukur pada skala berpengalaman-tidak berpengalaman, bergaya prefesional-tidak bergaya prefesional

- Faktor Dinamisme, dapat diukur pada skala agresif-tidak agresif, aktif-tidak aktif

- Faktor Objectivitas, dapat diukur pada skala berpandangan terbuka-tidak berpandangan terbuka, objektif-subjektif.

Kredibilitas yang dimiliki oleh komunikator tidak menentukan khalayak/komunikan berbeda dapat menangkap pesan yang sama walaupun melalui dari komunikator yang sama.

\section{Gerakan Sosial Baru}

Gerakan sosial baru (New Social Movement) yang berarti gerakan ini dibentuk untuk lebih menekankan pada kebebasan pada gerakan mereka sendiri tetapi tidak memiliki struktur organisasi yang birokratisasi melainkan memiliki tujuan atau issue perjuangan yang sama. Gerakan Sosial memiliki empat komponen mendasar dari tindakan sosial menurut Smelser (1962), yaitu;

- Memiliki tujuan atau nilai-nilai yang bersifat umum yang memberikan arahan secara luas dengan memiliki tujuan tertentu (purposive social behavior).

- Memiliki ketentuan-ketentuan upaya untuk mencapai tujuan tersebut, yang disebut dengan norma (norms).

- Mobilisasi sebagai energi individual untuk mencapai tujuan yang diinginkan. Pada tahapan ini, jika aktor yang dianggap adalah individu maka pertanyaan yang akan diajukan bagaimana ia sebagai aktor termotivasi pada hal tersebut dan bagaimana memotivasi individu-individu lainnya untuk terorganisasi bersama.

- Fasilitas situasional, dimana seorang aktor menggunakan sebagai sarana. Fasilitas yang dimaksudkan ini merupakan keterampilan, perangkat, pengetahuan, maupun mempertimbangkan untuk melakukan suatu tindakan.

Peneliti telah menemukan beberapa riset penelitian yang berkaitan dengan kasus Satinah maupun dengan teori kredibilitas komunikator. Penelitian pertama adalah penelitian Dewi Kartika Sari dan Royke R. Siahanenia yang berjudul Gerakan Sosial Baru di Ruang Publik Virtual pada Kasus Satinah. Metode yang digunakan yaitu metode penelitian kualitatif. Hasil penelitian adalah pemahaman mengenai aktivitas gerakan sosial dan wadah bagi gerakan sosial. Penelitian kedua, yakni penelitian yang dilakukan oleh Haidir Fitra Siagian. Penelitian Siagian berjudul Pengaruh Kredibilitas Komunikator Politik Untuk Mendapatkan Dukungan Khalayak dalam Pemilihan Umum dengan menggunakan teori Komunikasi Politik dan teori Kredibilitas Komunikator Politik. Metode yang digunakan yaitu metode penelitian kualitatif. Hasil penelitian adalah pengaruh kredibilitas komunikator memiliki peran penting dalam meraih kemenangan dalam kampanye yang ada. Penelitian ketiga adalah penelitian dari Johanes Eka Priyatma melakukan penelitian berjudul Potensi Teori Jejaring Aktor Untuk 
Memahami Inovasi Teknologi dengan menggunakan teori Jejaring Aktor (Actor Network Theory). Metode penelitian menggunakan metode kualitatif. Hasil penelitian adalah jejaring di awal mulai terbentuk dan tidak mampu menghasilkan aktor yang menjadi juru bicara yang bisa efektif memobilisasi para aktor tersebut. Penelitian keempat merupakan penelitian dari Nurrudin melakukan penelitian berjudul Media Baru dan Munculnya Revolusi Proses Komunikasi dengan menggunakan teori model Komunikasi Massa dan menggunakan metode

Page | 132 penelitian kualitatif. Hasil penelitian yang diperoleh adalah revolusi proses penyebaran pesan berawal dari satu arah (one step flow) kemudian menjadi banyak tahap (multistep flow), komunikasi interpersonal (tatap muka) perlu adanya konstruksi baru dan penelitian ini membuktikan bahwa teori komunikasi massa mengalami mengalami perkembangan baru.

\section{METODE PENELITIAN}

Metode penelitian yang digunakan dalam penelitian ini menggunakan metode dengan pendekatan kualitatif dengan jenis penelitian deskriptif. Data primer pada penelitian ini adalah wawancara dengan Melanie Subono, sedangkan data sekunder penelitian ini merupakan data yang diperoleh melalui buku, artikel ataupun arsip yang mendukung. Dalam proses pengumpulan data, peneliti wawancaara secara mendalam dengan Melanie Subono. Data hasil wawancara tersebut kemudian akan dianalisis. Teknik analisa data yang dilakukan peneliti dimulai dengan reduksi data dilanjutkan dengan interpretasi data, kemudian ditarik kesimpulan.

\section{PEMBAHASAN}

\section{Jaringan Komunikasi pada Kasus Kendeng dan Satinah}

Kemunculan kasus Kendeng dan Satinah memiliki ciri yang sama yaitu menarik perhatian masyarakat Indonesia. Namun, ada juga perbedaan jaringan komunikasi yang terbangun pada kedua gerakan tersebut.

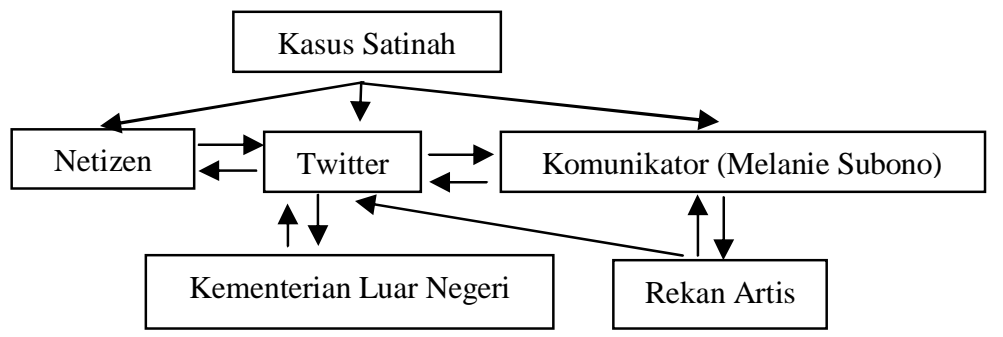

Gambar 1. Jaringan Komunikasi pada Kasus Satinah

Gambar 1 merupakan jaringan komunikasi yang terbentuk pada kasus Satinah. Munculnya kasus Satinah membuat Netizen terlibat. Keterlibatan netizen pada gerakan tersebut menggunakan Twitter. Selanjutnya, netizen secara bersama-sama dengan komunikator membuat relasi. Netizen, komunikator, rekan artis, dan Kementerian Luar Negeri (Kemenlu) berkomunikasi atau menyuarakan pendapatnya melalui Twitter. Rekan artis mendapatkan ajakan oleh komunikator untuk selanjutnya mengumpulkan dukungan dana atau dukungan dalam bentuk lain. Kemenlu menunjukkan kepeduliannya dengan memposting di Twitter. 


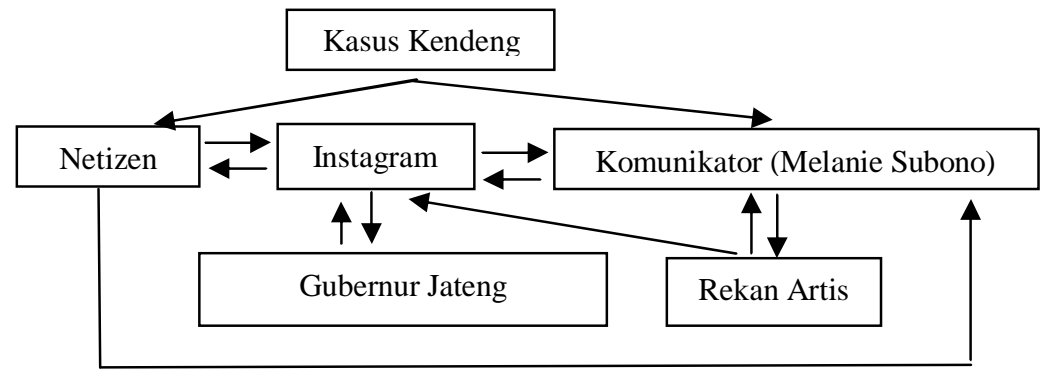

Page $\mid 133$

Gambar 2. Jaringan Komunikasi pada Kasus Kendeng

Gambar 2 menunjukkan keterlibatan jaringan komunikasi dari kemunculan kasus Kendeng yang melibatkan beberapa pihak, yaitu: netizen, Instagram, komunikator, rekan artis dan Gubernur Jawa Tengah. Munculnya kasus Kendeng membuat netizen terlibat. Keterlibatan netizen tersebut muncul pada postingan di Instagram. Melalui Instagram ini pula, komunikator dan rekan artis serta Gubernur Jawa Tengah berkomunikasi dan memberikan pendapat mereka.

\section{Gerakan Sosial Baru}

Terbentuknya jaringan komunikasi rupanya mampu menciptakan gerakan sosial. Menurut Smelser (1962), gerakan sosial memiliki empat komponen dasar. Berdasarkan keempat komponen dasar tersebut, maka penulis akan memaparkan hasil dari gerakan sosial pada kasus Satinah dan gerakan sosial pada kasus Kendeng.

\section{Gerakan Sosial pada Kasus Satinah} yaitu:

Kasus Satinah dalam empat komponen mendasar dari tindakan sosial menurut Smelser,

- Sekelompok anggota yang telah terbentuk memiliki nilai-nilai umum yang memberikan arahan yang luas terhadap perilaku setiap anggotanya dengan memiliki tujuan. Tujuan yang hendak dicapai dalam gerakan ini adalah kebebasan Satinah dari ancaman hukuman. Selain itu, tujuan yang hendak dicapai adalah memberikan bantuan dana atau pendampingan hukum kepada Satinah.

- Terbentuknya kelompok ini tetap mengikuti aturan-aturan negara Indonesia sebagai warga negara dan tetap mengadakan kumpul bersama untuk memanjatkan doa dari berbagai agama untuk Satinah.

- Mobilisasi aktor atau komunikator. Mobilisasi ini adalah mobilisasi yang dilakukan oleh Melanie Subono selaku komunikator. Hasil penelitian wawancara penulis, Melanie mengatakan: Pandanganku sama terhadap semua kasus yang aku tangani, pemerintah hanya melihat masyarakat untuk disuruh kerja tapi pemerintah yang menikmati hasilnya. Aku dapat pesan dari kakekku yaitu Bapak Habibie (mantan presiden RI) adalah kekayaan terbesar adalah terletak pada sumber daya manusianya, bahkan pemerintah lupa bahwa dirinya adalah manusia.

Pernyataan tersebut dituturkan pada kasus Satinah dan kasus Kendeng, hal tersebut yang memotivasi Melanie. Pesan dari kakeknya Habibie selaku mantan presiden RI, memotivasi Melanie untuk mengutamakan masyarakat yang memiliki hak manusiawi. Sementara pemerintah melupakan bahwa dirinya juga manusia sama seperti rakyat. Dalam tingkatan sosial, Melanie mengungkapkan bagaimana netizen termotivasi bergabung dalam kelompok ini:

"Setiap ada gerakan dalam kasus apapun, saya berusaha untuk menceritakan bagaimana masalah itu terjadi. Hingga membuat daya tarik sendiri masyarakat untuk melibatkan diri dan menimbulkan rasa kepedulian diri sendiri dari masalah tersebut, secara langsung masyarakat akan peduli dan sadar akan pengertian tersebut."

Daya tarik yang dimiliki Melanie Subono sebagai komunikator adalah dengan menceritakan kembali masalah atau kasus yang ia dukung serta menuangkan dalam versi 
Melanie sendiri. Hal tersebut sangat menarik perhatian netizen untuk menyadari bahwa dirinya memiliki hak dan kedudukan yang sama, kemudian ikut terlibat di dalam kasus tersebut.

Keempat komponen dasar tersebut, dapat melihat kasus membentuk tipe gerakan sosial menurut tipologi Aberle (1989) yaitu alterative moment. Kasus Satinah memiliki tipe alterative moment karena gerakan Save Satinah merubah pola pikir dan tingkah laku sebagian masyarakat Indonesia untuk terlibat dan membantu untuk kebebasan Satinah. Semakin dekat hari Satinah

Page | 134 dihukum pancung, masyarakat Indonesia justru semakin meningkat daya tariknya untuk terlibat dan membantu Satinah.

\section{Gerakan Sosial pada Kasus Kendeng}

Kasus Kendeng dalam empat komponen mendasar dari tindakan sosial menurut Smelser (1962), yaitu:

- Sekelompok anggota yang telah terbentuk memiliki nilai-nilai umum yang memberikan arahan yang luas terhadap perilaku setiap individunya dengan memiliki tujuan untuk mengembalikan hak rakyat dalam bentuk pekerjaan dan lahan rakyat.

- Terbentuknya kelompok ini tetap mengikuti aturan-aturan negara Indonesia sebagai warga negara dan mengadakan upacara bendera Merah Putih pada saat 17 Agustus.

- Mobilisasi yang dilakukan komunikator, yakni dengan memotivasi masyarakat. Berikut ini adalah kutipan wawancara dengan komunikator: "Pandanganku sama terhadap semua kasus yang aku tangani, pemerintah hanya melihat masyarakat untuk disuruh kerja tapi pemerintah yang menikmati hasilnya. Aku dapat pesan dari kakekku yaitu Bapak Habibie (mantan presiden RI) adalah kekayaan terbesar adalah terletak pada sumber daya manusianya, bahkan pemerintah lupa bahwa dirinya adalah manusia."

- Pernyataan tersebut dituturkan pada kasus Satinah dan kasus Kendeng, hal tersebut yang memotivasi Melanie. Pesan dari kakeknya Habibie selaku mantan presiden RI, memotivasi Melanie untuk mengutamakan masyarakat yang memiliki hak manusiawi. Sementara pemerintah melupakan bahwa dirinya juga manusia sama seperti rakyat.

- Dalam tingkatan sosial, Melanie mengungkapkan bagaimana netizen termotivasi bergabung dalam kelompok ini. Berikut ini adalah hasil wawancaranya:

"Setiap ada gerakan dalam kasus apapun, saya berusaha untuk menceritakan bagaimana masalah itu terjadi. Hingga membuat daya tarik sendiri masyarakat untuk melibatkan diri dan menimbulkan rasa kepedulian diri sendiri dari masalah tersebut, secara langsung masyarakat akan peduli dan sadar akan pengertian tersebut."

Daya tarik yang dimiliki Melanie Subono sebagai aktor dengan menceritakan kembali masalah atau kasus yang ia dukung serta menuangkan dalam versi Melanie sendiri, seperti bukti-bukti yang ia ketahui sendiri. Bukti-bukti yang didapatkan Melanie dalam kasus Kendeng, melakukan pembuktian beberapa lahan pegunungan Kendeng sebagai mata air sehingga berhak diperjuangkan. Melanie melakukan pembuktian tersebut dengan terjun langsung ke masyarakat dan melihat langsung kondisi yang terjadi. Hal tersebut sangat menarik netizen untuk sadar bahwa dirinya memiliki hak dan kedudukan yang sama lalu ikut terlibat di dalam kasus tersebut.

Keempat komponen dasar tersebut, dapat melihat kasus membentuk tipe gerakan sosial menurut tipologi Aberle yaitu reformative moment. Gerakan sosial kasus Kendeng ini dapat dikatakan reformative moment karena gerakan ini tidak menyetujui adanya pembangunan pabrik Semen di pegunungan Kendeng dan mempertahankan hak warga akan mata pencahariannya di pegunungan Kendeng. 
Vol. 10 No. 2

November 2018

\section{Kredibilitas Komunikator}

Melanie Subono memiliki faktor kredibilitas sebagai komunikator yang berbeda dalam kasus Satinah dan Kendeng. Faktor tersebut dipengaruhi bagaimana Melanie membangun jaringan komunikasi dalam setiap kasusnya dan gerakan sosial yang dilakukan Melanie Subono.

\section{Kredibilitas Melanie Subono dalam kasus Satinah}

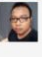

simple \#BEJO \#HOK

Ada yg ngedampingin gak waktu Satinah disidang? Gak ada. Harusnya diyat yg dibayar juga gak sebesar sekarang @kurawa cc @melaniesubono View details * $\leftarrow \neg \bullet$

melanie subono

Replying to @riosimple@kurawa

@riosimple@kurawa cuma kali ini karna aku ndampingin dari awal, jd ak tau terlalu banyak kbohongan d kasus ini yg ga keliatan orang lain View conversation $\leftarrow \mathrm{tz} \bullet$

Gambar 3. Tweet dari @ riosimple beserta tanggapan Melanie Subono Sumber : https://twitter.com/kurawa/status/449017489796526080

Gambar 3 merupakan data yang ditemukan peneliti dan Melanie memberikan opini kepada publik bahwa ia mendampingi kasus Satinah dari awal. Sesuai dengan kredibilitas sebagai komunikator, gambar 3 menunjukkan Melanie memiliki indikator profesionalisme. Melanie mampu memberikan opini tentang pengalamannya bahwa ia telah terjun langsung didalamnya dan memiliki sikap profesional dengan menjawab pertanyaan netizen dengan menyebutkan adanya kebohongan yang ia ketahui tetapi orang lain tidak mengetahuinya.

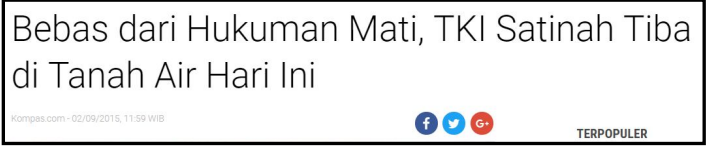

Gambar 4. Judul Berita pada kompas.com Sumber : https://nasional.kompas.com/read/2015/09/02/11595281/

Gambar 4 media Kompas.com memuat berita mengenai kebebasan Satinah pada 2 September 2015 dan Satinah telah tiba di Indonesia dengan terbebas dari segala hukuman. Berita tersebut memberikan bukti bahwa apa yang dilakukan Melanie untuk mengajak netizen berperan dan terlibat dalam kasus Satinah merupakan bukti yang benar dan jujur. Faktor kejujuran merupakan indikator kredibilitas kedua yang dimiliki Melanie Subono sebagai seorang komunikator.

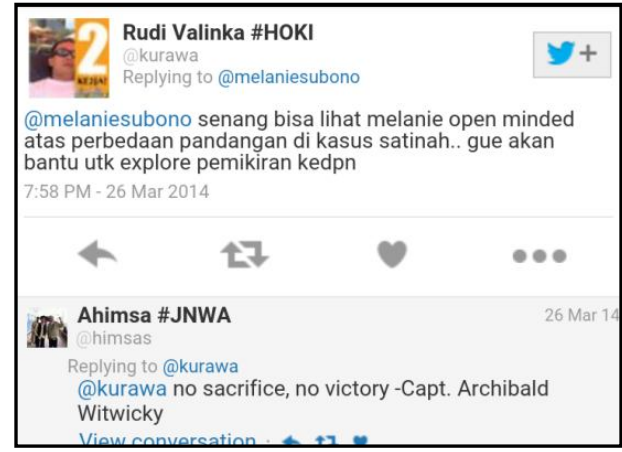

Gambar 5. Tweet dari @kurawa bentuk apresiasinya kepada Melanie Subono Sumber : : https://twitter.com/kurawa/status/449017489796526080 
Pernyataan @kurawa dalam gambar 5 mengakui bahwa Melanie Subono memiliki pemikiran yang luas dan memiliki pandangan yang berbeda dari beberapa orang. Hal ini diakui Melanie Subono ketika diwawancarai melalui Whatsapp, ia mengatakan:

"Saya gak selalu disudut masyarakat, bakal lihat dulu siapa yang bersalah di kasus ini dan saya bakal membela yang benar sesuai dengan fakta-fakta yang saya temuin.”

Kedua data tersebut menunjukkan bahwa Melanie masuk dalam indikator kredibilitas poin objektivitas, dimana Melanie memiliki sudut pandang yang terbuka mengenai kasus yang dihadapinya.

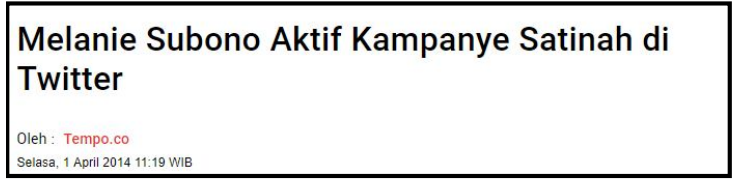

Gambar 6. Judul berita dalam Tempo.co Sumber : Tempo.co

Gambar 6 Tempo.co merupakan gambar dari salah satu media di Indonesia, yang memuat berita mengenai keaktifan Melanie Subono terlibat pada kasus Satinah. Kampanye yang dilakukan Satinah menjadi pusat perhatian media. Perhatian media terutama ketika meliput keaktifan Melanie dalam memperjuangkan kasus Satinah. Berita Kompas.co menunjukkan bahwa indikator dinamis dimiliki oleh Melanie Subono sebagai komunikator. Keaktifannya terus ada sampai Satinah dikatakan bebas dan kembali ke Tanah Air.

\section{Kredibilitas Melanie Subono dalam Kasus Kendeng}

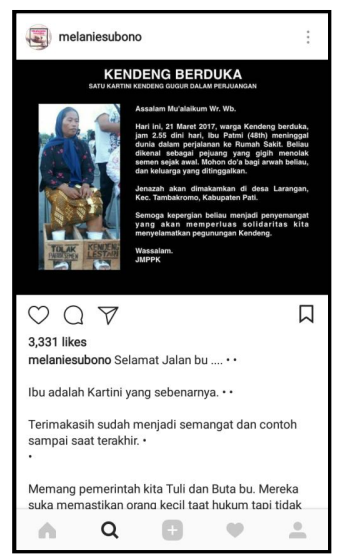

Gambar 7. Bentuk belasungkawa Melanie Subono kepada bu Patmi di Instagram Sumber : Instagram Melanie Subono

Gambar 7 menunjukkan kepedulian Melanie Subono atas meninggalnya Petani Kendeng yaitu $\mathrm{Bu}$ Patmi. Tulisannya yang mengucapkan selamat jalan kepada Bu Patmi serta memposting foto tersebut, menunjukkan Melanie memiliki indikator dinamis dalam kredibilitas komunikator. Faktor tersebut dapat dilihat dengan keaktifan Melanie untuk memposting dan memberikan empati terhadap kasus Kendeng yang sedang dialami.

Secara langsung, peneliti melakukan penelitian di Pati Jawa Tengah pada tanggal 17 Agustus 2017. Peneliti melihat langsung Melanie terjun pada warga dan mengumpulkan buktibukti yang perlu diperjuangkan untuk mendapatkan hak rakyat. Tidak hanya mengumpulkan bukti, Melanie ikut ke bawah sungai yang dianggap sebagai mata air Pati. Hal tersebut, menunjukkan bahwa apa yang dikumpulkan oleh Melanie dan diberikan kepada warga mengenai kasus Kendeng, memenuhi kriteria kejujuran dalam kredibilitas komunikator. Faktor 
kejujuran yang dimiliki Melanie diukur dari kebenaran adanya fakta dan data yang diberikan sesuai dengan apa yang terjadi dilapangan.

\section{KESIMPULAN}

Jaringan Komunikasi yang dilakukan Melanie Subono memiliki keunikan masing-masing di setiap kasus, entah dalam kasus Kendeng maupun dalam kasus Satinah. Keunikannya, kasus Satinah berhasil diselesaikan. Pada kasus Kendeng, sampai tahun 2017 saat penulis bertemu secara langsung dengan Melanie Subono, kasus tersebut masih berlangsung. Jaringan Komunikasi yang dibangun oleh Melanie Subono menimbulkan adanya gerakan sosial dari setiap kasusnya. Gerakan sosial yang dilakukan oleh Melanie Subono pada kedua kasus tersebut memiliki perbedaan. Kasus Satinah dan Kendeng memiliki tipe gerakan sosial yang berbeda. Tipe gerakan sosial pada kasus Satinah merupakan tipe gerakan sosial alterative moment dan tipe gerakan sosial pada kasus Kendeng merupakan tipe gerakan sosial reformative moment.

Hasil penelitian yang diperoleh oleh peneliti, dalam kasus Satinah Melanie Subono memiliki kriteria profesionalisme, kriteria kejujuran, kriteria objektivitas, dan kriteria dinamis. Disisi lain, peneliti menemukan perbedaan dalam kasus Kendeng, Melanie memiliki kriteria dinamis dan kriteria kejujuran. Hasil penelitian tersebut dapat disimpulkan, Melanie Subono memiliki kredibilitas sebagai komunikator dalam kasus Satinah karena berhasil membangun jaringan komunikasi dan memiliki 4 bukti kriteria kredibilitas komunikator. Kasus Kendeng Melanie Subono belum dapat dikatakan memiliki kredibilitas sebagai komunikator karena kasus tersebut masih berlangsung. Melanie hanya memiliki dua kriteria kredibilitas sebagai komunikator.

\section{DAFTAR PUSTAKA}

Admin. (2017). Pernyataan Keras Melanie Subono Terkait Kematian Padmi, Petani Kendeng Nusantara. Diakses melalui http://www.nusantarasatu.net/2017/03/pernyataan-kerasmelanie-subono-terkait.html 27 Mei 2017 (00:11)

Alfindasari, Desy. (2014). Teknik Pengumpulan Data Dalam Penelitian Kualitatif. Diakses melalui http://www.eurekapendidikan.com/2014/11/teknik-pengumpulan-datadalam.html 16 Mei 2017 (20:49)

Andrianthy, Novi. (2009). Gerakan Sosial : Akvitisme Gemkara-BP3KB dan Pengaruhnya dalam Mewujudkan Kabupaten Batubara. Diakses melalui http://repository.usu.ac.id/bitstream/handle/123456789/14850/09E01247.pdf?sequenc e=1\&isAllowed=y 15 Mei 2018 (23:16)

Bachri, Bachtiar S. (2010). Meyakinkan Validitas Data Melalui Triangulasi Pada Penelitian Kualitatif. Surabaya : Universitas Negeri Surabaya. Diakses melalui http://yusuf.staff.ub.ac.id/files/2012/11/meyakinkan-validitas-data-melalui-triangulasipada-penelitian-kualitatif.pdf 20 Mei 2017 (12:23)

Chandra, Ni Made Herma Kristiana. (2011). Pengaruh Kredibilitas Customer Service London Beauty Centre Terhadap Kepuasan Pelanggan : Studi Pada Kantor Pusat London Beauty Centre Yogyakarta. Yogyakarta : Universitas Pembangunan Nasional Veteran. Diakses melalui http://repository.upnyk.ac.id/1522/1/skripsi.pdf 24 Mei 2017 $(17: 27)$

Darry, Mohammad. (2014). Gerakan Sosial Politik. Diakses melalui http://mohammad-darryfisip12.web.unair.ac.id/artikel_detail-94652-

Gerakan\%20Sosial\%20dan\%20Politik\%20Identitas-

Gerakan\%20Sosial\%20Politik.html 15 Februari 2018 (13:46)

Edi, Purnomo. (2017). Aktivis Yogya Peringati 40 Hari Meninggalnya Patmi Kartini Kendeng. Diakses melalui https://www.merdeka.com/peristiwa/aktivis-yogya-peringati-40-harimeninggalnya-patmi-kartini-kendeng.html 27 Mei 2017 (01:16) 
Ginanjar, Ging. (2017). Penyelundupan Hukum dalam Kasus Izin Pabrik Semen di Kendeng. Diakses melalui http://www.bbc.com/indonesia/indonesia-39321180 26 Mei 2017 (21:42)

Hapsari, Dwi Retno. 2016. Jurnal Komunikasi : Peran Jaringan Komunikasi dalam Gerakan Sosial Untuk Pelestarian Hidup. Indonesia : Ikatan Sarjana Komunikasi Indonesia (ISKI)

Page | 138 Herwandito, Seto. 2015. Menyelami Benak Komunikator (Studi Pada Pembuatan Pesan Pada Kesenian Wayang Waton Oleh Komunikator). Salatiga : Jurnal Cakrawala Volume IV (No.2) Juni $2015: 79-108$

Ihsanuddin. (2017). Petani Kendeng Menang di MA Lawan PT Semen Indonesia. Diakses melaluihttp://nasional.kompas.com/read/2016/10/12/09164211/petani.kendeng.menan g.di.ma.lawan.pt.semen.indonesia 26 Mei 2017 (21:24)

Light, Keller dan Craig Calhoum. Sosiology. (New York, Edisi Kelima, Alfred A. Knopf,1989). 599-600

Maulidi, Achmad. (1962). Pengertian Data Primer dan Data Sekunder. Diakses melalui https://www.kanalinfo.web.id/2016/10/pengertian-data-primer-dan-datasekunder.html 20 Mei 2017 (18:39)

Smelser, Neil J. 2014. Theory of Collective Behavior. (London: Routledge and Kegan Paul and New York Free Pass of Gilence,1962). 17-18

Nurdiani, Nina. (2014). Teknik Sampling Snowball dalam Penelitian Lapangan. Jakarta : Architecture Department, Faculty of Engineering BINUS University. Diakses melalui http://researchdashboard.binus.ac.id/uploads/paper/document/publication/Proceeding/ ComTech/Volume\%205\%20No\%202\%20Desember\%202014/55_AR_Nina\%20Nurdi ani_OK_a2t.pdf 19 Mei 2017 (18:54)

Nurrudin. 2013. Media Sosial Baru dan Munculnya Revolusi Proses Komunikasi. Yogyakarta : Jurnal Komunikator Universitas Muhammadiyah Yogyakarta. Diunduh melalui http://journal.umy.ac.id/index.php/jkm/article/view/207/169 21 Maret 2018 (18.09).

Pratama, Fajar. (2017). Patmi, Petani Kendeng Peserta Aksi Semen Kaki Meninggal Dunia. Diakses melalui https://news.detik.com/berita/d-3452359/patmi-petani-kendengpeserta-aksi-semen-kaki-meninggal-dunia 25 Mei 2017 (20:40)

Priyatma, Johanes Eka. (2013). Potensi Teori Jejaring Aktor Untuk Memahami Inovasi Teknologi. Yogyakarta : Teknik Informatika Sanata Dharma. Diakses melalui https://repository.usd.ac.id/4456/1/475_Eka-Memahami+Inovasi+Makalah+RiTekTra2013.pdf 1 September 2017 (15:07)

Purnomo, Daru. et. al. 2016. Pedoman Tata Tulis Ilmiah. Salatiga : Fakultas Ilmu Sosial dan Ilmu Komunikasi UKSW

Pusat Humas Kementrian Perdagangan RI. (2014). Panduan Optimalisasi Media Sosial Untuk Kementrian Perdagangan Sosial. Jakarta : Pusat Hubungan Masyarakat. Diakses melalui http://www.kemendag.go.id/files/pdf/2015/01/15/buku-media-sosialkementerian-perdagangan-id0-1421300830.pdf 16 Mei 2017 (16:49)

Putra, et.al., 2006. Gerakan Sosial, Konsep, Strategi, Aktor, Hambatan dan Tantangan Gerakan Sosial di Indonesia. Malang : PlaCID's dan Averroes Press

Rahardjo, H Mudjia. (2017). Studi Kasus dalam Penelitian Kualitatif: Konsep dan Prosedurnya. Malang : Universitas Islam Negeri Maulana Malik Ibrahim. Diakses melalui http://repository.uin-malang.ac.id/1104/1/Studi-kasus-dalam-penelitiankualitatif.pdf 20 Mei 2017 (20:22)

RI, Kemlu. (2015). Diakses https://twitter.com/Kemlu_RI/status/639373794532954112 13 Maret 2018 (18:15)

Risky. (2016). Teknik Analisis Data Kualitatif, Kuantitatif Menurut Para Ahli (Lengkap). Diakses melalui https://pastiguna.com/teknik-analisis-data/ 12 Januari 2018 (16:48).

Royanto, Dwi. (2017). Gaya Melanie Subono Berjuang Bersama Kartini Kendeng. Diakses melalui http://www.viva.co.id/berita/nasional/871825-gaya-melanie-subono-berjuangbersama-kartini-kendeng 26 Mei 2017 (23:12)

Saputra, Imam Yudha. (2017). Kaki Petani Kendeng Disemen, Ini Kata Ganjar. Diakses melalui http://www.solopos.com/2017/03/18/pabrik-semen-kendeng-kaki-petanikendeng-disemen-ini-kata-ganjar-802562 26 Mei 2017 (22:07) 
Vol. 10 No. 2

November 2018

Sari, Dewi Kartika dan Royke R.Siahaninenia. (2015). Gerakan Sosial Baru di Ruang Publik Virtual pada Kasus Satinah. Yogyakarta : Fakultas Ilmu Politik Universitas Atma Jaya. Diunduh melalui https://doi.org/10.24002/jik.v12i1.446 10 Agustus 2017

Siagian, Haidir Fitra. (2012). Pengaruh Kredibilitas Komunikator Politik Untuk Mendapatkan Dukungan Khalayak dalam Pemilihan Umum. Malaysia : Univesitas Kebangsaan. Diakses melalui https://media.neliti.com/media/publications/76108-ID-pengaruhkredibilitas-komunikator-politi.pdf 23 Mei 2017 (12:22)

Sugiyono. 2003. Metode Penelitian Bisnis. Bandung : Pusat Bahasa Depdiknas

Suhendi, Adi. (2014). Cerita Panjang Satinah dari Mencari Riyal sampai Divonis Hukuman Mati. Diakses melalui http://www.tribunnews.com/nasional/2014/03/27/ceritapanjang-satinah-dari-mencari-riyal-sampai-divonis-hukuman-mati?page=2 25 Maret 2018 (18:10)

Suprapto, Tommy. (2009). Pengantar Teori dan Manajemen Komunikasi. Diakses melalui https://books.google.co.id/books?hl=id\&lr=\&id=xtHs4pLWdqAC\&oi=fnd\&pg=PA1 $\& \mathrm{dq}=$ teori+komunikasi+mengenai+komunikator\&ots=JgOZGEQQh4\&sig=2E9EXCu $\mathrm{Nj} 191$ pq8NqyaECY66d1Q\&redir_esc=y\#v=onepage\&q=teori\%20komunikasi\%20me ngenai\%20komunikator\&f=false 22 Mei 2017 (10:32)

Suprapto, Tommy. 2009. Pengantar Teori dan Manajemen Komunikasi. Yogyakarta : MedPress (Anggota IKAPI)

Surbakti, Nurhayati \& Silalahi, Siska Maria Eviline. (2008). Pengaruh Kredibilitas Pegawai Dalam Komunikasi Interpersonal Terhadap Sikap Nasabah Pada Perusahaan. Bandung : Universitas Katolik Parahyangan. Diakses melalui https://www.google.co.id/url?sa=t\&rct=j\&q=\&esrc=s\&source=web\&cd=10\&cad=rja \&uact=8\&ved=0ahUKEwie46HT6fbVAhXKpY8KHcN3CScQFghgMAk\&url=http\% 3A\%2F\%2Fjournal.unpar.ac.id\%2Findex.php\%2FJurnalAdministrasiBisnis\%2Farticl e\%2Fdownload\%2F361\%2F345\&usg=AFQjCNFBH5qDjxp6CHRGm7WM3cWOU Wgvsg 24 Mei 2017 (13:15)

Susanto, Eko Hari. (2016). Komunikasi dan Gerakan Perubahan: Kemajemukan dalam Konstelasi Sosial, Ekonomi, Politik. Jakarta : Mitra Wacana Media. Diakses melalui http://yusuf.staff.ub.ac.id/files/2012/11/meyakinkan-validitas-data-melalui-triangulasipada-penelitian-kualitatif.pdf 21 Mei 2017 (10:35).

Tempo. (2014). Melanie Subono Aktif Kampanye Satinah di Twitter. Diakses melalui https://seleb.tempo.co/read/566916/melanie-subono-aktif-kampanye-satinah-di-twitter 21 Januari 2018 (18:17).

Wahono, Tri. (2015). Bebas dari Hukuman Mati, TKI Satinah Tiba di Tanah Air Hari Ini. Diakses melalui https://nasional.kompas.com/read/2015/09/02/11595281/ 20 Februari 2018 (18:12)

Widiarni, Fransisca Nike. (2013). Intensi Untuk Mengikuti Kegiatan Organisasi Sosial Pada Pensiunan. Bandung : Universitas Pendidikan Indonesia. Diunduh melalui http://repository.upi.edu/428/6/S_PSI_0703833_CHAPTER3.pdf 18 Mei 2017 (15:46).

Wiryanto. (2004). Pengantar Ilmu Komunikasi. Jakarta : Grasindo. Diakses melalui https://books.google.co.id/books?id=QkBm4nO27r0C\&printsec=frontcover\&hl=id\&s ource=gbs_ge_summary_r\&cad=0\#v=onepage\&q\&f=false 17 Mei $2017(14: 22)$

Yunita, Niken Widya. (2017). Cerita Warga Sekitar Pabrik Semen Rembang Tentang Demo Pro-Kontra. Diakses melalui https://news.detik.com/berita/d-3452919/cerita-wargasekitar-pabrik-semen-rembang-tentang-demo-pro-kontra 25 Mei 2017 (18:26) 